\title{
PENGGUNAAN TEPUNG GAPLEK SEBAGAI SUBTITUSI TEPUNG TERIGU DALAM PEMBUATAN BOLU KUKUS
}

\author{
Marya Yenny \\ Sekolah Tinggi Pariwisata Sahid, Jakarta, yennymarya@yahoo.co.id
}

\begin{abstract}
ABSTRAK:
Cake pada awalnya telah dikenal oleh bangsa Mesir Kuno tetapi sebenarnya berasal dari daratan Eropa dan diperkenalkan kepada masyarakat Indonesia oleh bangsa Belanda selama masa penjajahan. Pada dasarnya, bolu kukus terbuat dari tepung terigu sebagai bahan dasar tepung yang digunakan. Tetapi disini, peneliti menggunakan tepung gaplek sebagai pengganti dari tepung terigu. Produk ini memiliki kandungan gizi yang tinggi, 14 kandungan karbohidrat dibanding sumber karbohidrat lain. Selain itu, tepung gaplek memiliki kandungan serat yang tinggi dan kandungan gula yang rendah sehingga baik bagi pencernaan. Pengolahan lebih lanjut menjadi aneka kue akan mengatasi rendahnya kandungan protein tepung gaplek. Melalui penggunaan tepung gaplek sebagai subtitusi tepung terigu diharapkan dapat meningkatkan penggunaan tanaman pangan lokal secara maksimal yang akan berefek mengurangi penggunaan terigu serta menekan jumlah impor tepung terigu dari luar yang pada akhirnya membuat ketahanan pangan Indonesia semakin bertambah kuat. Metode yang digunakan dalam penelitian ini adalah pengujian sensoris dengan metode uji kesukaan (hedonik) dan uji pembedaan (mutu hedonik) menggunakan Rancangan Acak Lengkap (RAL) dengan perhitungan statistik menggunakan one way ANNOVA $(\alpha=5 \%)$. Hasil terbaik yang paling disukai adalah bolu kukus dengan subtitusi 50\% tepung gaplek dengan karakteristik warna coklat, aroma dari coklat bubuk, tekstur bolu kukus yang lembut dan rasa dari coklat bubuk.
\end{abstract}

Kata Kunci: bolu kukus, bahan pengganti, uji coba, tepung gaplek

\section{PENDAHULUAN}

Pertanian mempengaruhi konsumsi pangan manusia yang saat ini terbatas pada beberapa jenis tanaman pangan. Secara global, 80 persen total asupan energi diperoleh hanya dari 12 spesies. Delapan diantaranya berasal dari jenis serealia seperti jagung, padi, rye, millet, barley, sorgum, tebu dan gandum. Sementara empat lainnya dari jenis umbi-umbian yaitu singkong, kentang, ubi jalar dan yam. Menurut kekayaan pangan lokal yang ada apabila dikembangkan dapat menjadi aset yang memiliki andil besar dalam perekonomian dan kedaulatan pangan Indonesia. Misalnya saja umbi-umbian seperti ubi jalar, garut, ganyong dan ubi kayu. Ubi kayu atau singkong berasal dari Brazilia. Dalam sistematika tumbuhan, ubi kayu termasuk ke dalam kelas Dicotyledoneae. Ubi kayu merupakan salah satu jenis umbi-umbian yang menjadi sumber bahan baku utama pembuatan bioetanol karena mempunyai kemampuan untuk tumbuh di tanah yang tidak subur, tahan terhadap serangan hama penyakit dan dapat diatur masa panennya. Pemanfaatan ubi kayu dalam bentuk tepung dapat mesubtitusikan tepung terigu sehingga dapat mengurangi ketergantungan akan tepung terigu yang cukup tinggi. Selain itu dapat memperluas penggunaannya menjadi 


\section{National Conference of Creative Industry: \\ Sustainable Tourism Industry for Economic Development}

Universitas Bunda Mulia, Jakarta, 5-6 September 2018 e-ISSN No: 2622-7436

berbagai bentuk olahan. Ubi kayu mempunyai potensi sebagai bahan baku tepung mengingat kandungan karbohidrat dan vitamin $\mathrm{C}$ yang cukup tinggi. Saat ini tepung gaplek (ubi kayu) bisa di dapat dari produsen. Selain itu, dalam kehidupan sehari-hari masyarakat kurang memanfaatkan tepung gaplek menjadi produk yang bernilai ekonomis. Pemilihan tepung gaplek sebagai bahan subtitusi karena kandungan gizi yang tinggi, karbohidrat yang tinggi yang memungkinkan menjadi pengganti nasi, kandungan serat yang cukup tinggi baik untuk pencernaan dan kandungan gula yang rendah. Tepung gaplek dapat digunakan sebagai bahan baku utama ataupun bahan campuran dalam pembuatan roti, kue-kue, mie dan makanan bayi ataupun produk olahan makanan lain. Kue merupakan kudapan atau makanan ringan. Kue seringkali diartikan sebagai makanan ringan yang terbuat dari adonan tepung. Baik tepung beras, tepung sagu, tapioka ataupun terigu. Biasanya kue bercita rasa manis namun ada pula kue yang bercita rasagurihatauasin.Kuedapatdikategorikanberdasarkan kadar airnya, yaitu kue basah dan kering. Bolu kukus merupakan salah satu cirri dari kue basah. Bolu kukus adalah kue berbahan dasar tepung (umumnya tepung terigu), gula, dan telur.

Berdasarkan variabel yang ada, maka penulis mengidentifikasikan beberapa masalah, yaitu masih kurangnya minat masyarakat untuk mengkonsumsi ubi kayu, pengolahan ubi kayu masih terbatas dan sederhana, layaknya di kukus atau di goreng, dan kurangnya pengetahuan masyarakat tentang bahan panganlokal.

\section{TINJAUAN PUSTAKA}

Ketela pohon atau ubi kayu merupakan tanaman perdu. Ketela pohon berasal dari benua Amerika, tepatnya dari Brazil. Penyebarannya hampir ke seluruh dunia, antara lain Afrika, Madagaskar, India dan Tiongkok. Tanaman ini masuk ke Indonesia pada tahun 1852. Ketela pohon berkembang di negara- negara yang terkenal dengan wilayah pertaniannya. Ubi kayu (Manihot esculenta Crantz) merupakan jenis tanaman yang termasuk famili Eupharbiaceae dan genus Manihot. Batangnya berkayu dan tumbuh tegak beruas dan berbuku-buku. Warnanya bermacam-macam dan tingginya dapat mencapai 3 meter. Warna batang hijau muda dan setelah tua berubah menjadi putih kelabu atau hijau kelabu, meskipun satu dua ada yang berubah jadi coklat. Daun tumbuh di sepanjang batang dengan tangkai yang agak panjang. Daunnya mudah gugur dan yang berdaun biasanya hanya batang bagian atas dekat pucuk. Bunganya berumah satu dan kematangan bunga betina dan bunga jantan berbeda waktunya sehingga persarian (penyerbukan) terjadi dengan persilangan.

Ubi kayu juga merupakan jenis tanaman yang dapat tumbuh di sembarang tempat. Apalagi di kawasan tropis dengan penyinaran penuh sepanjang tahun seperti Indonesia. Tanaman ini tumbuh baik di daerah berhawa panas dan banyak turun hujan, biasanya ditanam di daerah rendah sampai pegunungan dengan ketinggian 1.500 meter di atas permukaan laut. Lazimnya diperbanyak dengan stek.

Tepung gaplek (Manihot Esculenta Crantz): salah satu produk olahan dari bahan gaplek yang dikeringkan kemudian dihaluskan dengan 80 mes. Tepung gaplek memiliki warna yang lebih putih kecoklatan dan memiliki aroma harum dan khas. Tepung gaplek mempunyai kegunaan yang cukup banyak dalam pengolahan makanan seperti halnya tepung terigu, tepung gaplek ini dapat digunakan sebagai bahan utama ataupun bahan campuran dalam pembuatan roti, kue-kue, mie dan makanan bayi ataupun produk olahan makanan lain. (Siswono,2005). 


\section{National Conference of Creative Industry: \\ Sustainable Tourism Industry for Economic Development}

Universitas Bunda Mulia, Jakarta, 5-6 September 2018 e-ISSN No: 2622-7436

Bolu kukus: berasal dari daratan Eropa dan diperkenalkan kepada masyarakat Indonesia oleh bangsa Belanda selama masa penjajahan. Kue bolu adalah kue berbahan dasar tepung (umumnya tepung terigu, gula dan telur). Kue bolu umumnya dimasak dengan cara dipanggang di oven, walaupun ada juga yang namanya bolu kukus. Banyak macam kue bolu, misalnya kue tart yang biasa digunakan untuk acara pesta pernikahan dan harirayaulang tahun dan bolu juga bisa digunakan untuk acara-acara lainnya (Veranita, 2012).

Adapun pengertian lainnya, bolu adalah kue berbahan dasartepung biasanya menggunakan tepungterigu, gula dan telur. Kue bolu umumnya dimatangkan dengan 2 cara dipanggang di dalam oven dan dikukus. Faktor keberhasilan dalampembuatan bolu kukus adalah dalam cara mengocok adonan dan mengukus adonan, misalnya mengocoknya terlalu lama atau terlalu sebentar ataupun pengukusannya tidak sempurna bisa membuat bolu kukus tidak mengembang (Rohimah,2008).

Tepung terigu: salah satu dari dua bahan pembentuk susunan yang dipergunakan dalam produk-produk bakery. Tepung terigu yang dipergunakan di pabrik roti pada umumnya diperoleh dari gandum yang telah digiling. Karena terigu merupakan salah satu bahan utama dan sangat esensial (Suhardjito, 2006). Adapun pengertian lainnya, tepung terigu merupakan hasil olahan dari gandum. Tanpa tepung terigu tidak akan dapat membuat produk bakery dengan baik. Tepung terigu memiliki tiga macam kandungan protein yaitu, hard flour atau tepung berprotein tinggi, medium flour yang biasa disebut terigu berprotein sedang, dan soft flour yang terbuat dari gandum lunak atau bisa disebut terigu protein rendah. (Anni Faridah, 2008). Tekstur: struktur bentuk mutu pangan yang dapat di indera melalui pengigitan, pengelihatan atau pendengaran. (Nurosiyah Siti dan Winiati P. Rahayu,2012).

Rasa: struktur bentuk mutu pangan yang dapat di indera melalui penggigitan, pengelihatan atau pendengaran. (Nurosiyah Siti dan Winiati P. Rahayu,2012) Warna: spektrum tertentu yang terdapat di dalam suatu cahaya sempurna atau berwarna putih. (Wikipedia). Aroma: kesan yang diterima alat penciuman dengan konotasi positif. (Nurosiyah Siti dan Winiati P. Rahayu, 2012).

\section{METODE PENELITIAN}

Metode penelitian yang digunakan pada penelitian ini adalah metode eksperimental. Dalam penelitian ini sebagai bahan manipulasi kontrol, penulis melakukan empat kali uji coba dengan perbedaan bahan terdapat pada komposisi tepung terigu dan tepung ubi kayu. Percobaan 1 menggunakan komposisi tepung ubi kayu 25\% dan tepung terigu $75 \%$, kemudian pada percobaan 2, menggunakan komposisi tepung ubi kayu $50 \%$ dan tepung terigu $75 \%$, sedangkan pada perlakuan 3 menggunakan komposisi tepung ubi kayu $75 \%$ dan tepung terigu $25 \%$, dan pada percobaan 4 atau yang terakhir menggunakan komposisi tepung ubi kayu $100 \%$.

Dalam menganalisis penelitian ini, dilakukan percobaan dengan pembuatan bolu kukus dengan menggunakan bahan dasar tepung terigu dan tepung ubi kayu yang hasilnya penulis sudah menyebarkan kuesionerkepada 25 mahasiswa/i yang masih aktif. Penulis menggunakan pengumpulan data dari panelis yang akan melakukan penilaian kualitas dan tingkat kesukaan dari bolu kukus yang dihasilkan dengan beberapa tingkat subtitusi tepung ubi kayu dengan tepung terigu. Bahan yang digunakan untuk penelitian 
ini adalah tepung gaplek yang diproduksi oleh produsen di daerah Klaten, Jawa Tengah. Bahan-bahan untuk membuat bolu kukus yaitu tepung terigu dengan merk cakra kembar (medium flour), gula dengan merk gulaku, telur yang dibeli di toko anugerah pasar grogol, soda tawar (air berkarbonasi) dengan merk cloe, cake emulsifier dengan merk koepoe-koepoe, baking powder dengan merk hercules, vanilla essens dengan merk koepoe- koepoe, chocolate powder dengan merk cocoa vanhouten.

Peralatan dapur yang digunakan untuk membuat bolu kukus adalah timbangan, bowl, mixer dengan miyako, spatula dengan merk lion star, ladle, loyang, steamer dengan merk bima, kompor dengan merkrinai.

Lokasi penelitian uji coba subtitusi tepung terigu dengan tepung gaplek dalam pembuatan bolu kukus di rumah peneliti sendiri di Jl. Dr. Muwardi 2A No. 23, Grogol, Jakarta Barat. Uji sensoris dilakukan dilingkungan Sekolah Tinggi Pariwisata Sahid Jakarta kampus 3, di Sahid Hotel, Gedung Sahid Residence lantai 5, Jl. Jenderal Sudirman No. 86, Jakarta Pusat.

\section{HASIL PENELITIAN DAN PEMBAHASAN}

Setelah melakukan penelitian pendahuluan terhadap uji coba subtitusi tepung terigu dengan tepung gaplek dalam proses pembuatan bolu kukus, maka didapatilah hasil bahwa pembuatan bolu kukus dapat diolah dengan subtitusi 100\% tepung gaplek, sehingga peneliti bisa menggunakan 4 sampel sebagai bahan uji coba, yaitu sampel dengan 25\% tepung gaplek, 50\% tepung gaplek, $75 \%$ tepung gaplek dan $100 \%$ tepunggaplek. Dalam uji kesukaan/ uji hedonik terhadap subtitusi tepung gaplek dengan tepung terigu meliputi beberapa indikator yaitu warna, aroma, tekstur dan rasa.

Pada indikator warna, dari hasil uji hedonik warna menurut 25 panelis agak terlatih menunjukkan pada pengulangan pertama sampel yang paling disukai, yaitu sampel dengan kode 075 (50\% tepung gaplek), pada pengulangan kedua sampel yang paling disukai, yaitu sampel dengan kode 705 (50\% tepung gaplek) dan pada pengulangan ketiga sampel yang paling disukai, yaitu sampel dengan kode 570 (50\% tepung gaplek). Secara keseluruhan pengulangan $(1,2,3)$ nilai rata-rata yang paling tinggi yaitu 4,28 (50\% tepung gaplek) pada sampel 705 di pengulangan kedua.

Tabel 1. Uji Hedonik Warna

\begin{tabular}{|c|c|c|c|c|c|}
\hline Sampel & Rata-rata & Sampel & Rata-rata & Sampel & Rata-rata \\
\hline \multicolumn{2}{|c|}{ Pengulangan 1 } & \multicolumn{2}{|c|}{ Pengulangan 2 } & \multicolumn{2}{c|}{ Pengulangan 3 } \\
\hline $\mathbf{1 5 2}$ & 3,96 & $\mathbf{2 1 5}$ & 3,6 & $\mathbf{5 1 2}$ & 3,36 \\
\hline $\mathbf{7 5}$ & 4,08 & $\mathbf{7 0 5}$ & 4,28 & $\mathbf{5 7 0}$ & 4,12 \\
\hline $\mathbf{5 0 7}$ & 3,68 & $\mathbf{5 7}$ & 3,88 & $\mathbf{7 0 5}$ & 3,88 \\
\hline $\mathbf{1 1 2}$ & 3,76 & $\mathbf{2 1 1}$ & 3,72 & $\mathbf{1 2 1}$ & 4,04 \\
\hline
\end{tabular}

Sumber: Olahan Penulis

Pada indikator aroma, dari hasil uji hedonik aroma menurut 25 panelis agak terlatih menunjukkan pada pengulangan pertama sampel yang paling disukai, yaitu sampel dengan kode 075 (50\% tepung gaplek), pada pengulangan kedua sampel yang paling disukai, yaitu sampel dengan kode 705 (50\% tepung gaplek) dan pada 
pengulangan ketiga sampel yang paling disukai, yaitu sampel dengan kode 570 (50\% tepung gaplek). Secara keseluruhan pengulangan $(1,2,3)$ nilairata-rata yang paling tinggi yaitu 4,04 (50\% tepung gaplek) pada sampel 570 di pengulangan ketiga.

\section{Tabel 2. Uji Hedonik Warna}

\begin{tabular}{|c|c|c|c|c|c|}
\hline Sampel & Rata-rata & Sampel & Rata-rata & Sampel & Rata-rata \\
\hline \multicolumn{2}{|c|}{ Pengulangan 1 } & \multicolumn{2}{|c|}{ Pengulangan 2 } & \multicolumn{2}{c|}{ Pengulangan 3 } \\
\hline $\mathbf{1 5 2}$ & 3,72 & $\mathbf{2 1 5}$ & 3,76 & $\mathbf{5 1 2}$ & 3,2 \\
\hline $\mathbf{7 5}$ & 4 & $\mathbf{7 0 5}$ & 3,84 & $\mathbf{5 7 0}$ & 4,04 \\
\hline $\mathbf{5 0 7}$ & 3,8 & $\mathbf{5 7}$ & 3,8 & $\mathbf{7 0 5}$ & 3,68 \\
\hline $\mathbf{1 1 2}$ & 3,32 & $\mathbf{2 1 1}$ & 3,8 & $\mathbf{1 2 1}$ & 3,76 \\
\hline
\end{tabular}

Sumber: Olahan Penulis

Pada indikator tekstur, dari hasil uji hedonik tekstur menurut 25 panelis agak terlatih menunjukkan pada pengulangan pertama sampel yang paling disukai, yaitu sampel dengan kode 152 (25\% tepung gaplek) dan 075 (50\% tepung gaplek), pada pengulangan kedua sampel yang paling disukai, yaitu sampel dengan kode 057 (75\% tepung gaplek) dan pada pengulangan ketiga sampel yang paling disukai, yaitu sampel dengan kode 570 (50\% tepung gaplek). Secara keseluruhan pengulangan $(1,2,3)$ nilai rata-rata yang paling tinggi yaitu 4,12 (50\% tepung gaplek) pada sampel 570 di pengulangan ketiga.

Tabel 3. Uji Hedonik Tekstur

\begin{tabular}{|c|c|c|c|c|c|}
\hline Sampel & Rata-rata & Sampel & Rata-rata & Sampel & Rata-rata \\
\hline \multicolumn{2}{|c|}{ Pengulangan 1 } & \multicolumn{2}{|c|}{ Pengulangan 2 } & \multicolumn{2}{c|}{ Pengulangan 3 } \\
\hline $\mathbf{1 5 2}$ & 3,84 & $\mathbf{2 1 5}$ & 3,48 & $\mathbf{5 1 2}$ & 3,68 \\
\hline $\mathbf{7 5}$ & 3,84 & $\mathbf{7 0 5}$ & 3,64 & $\mathbf{5 7 0}$ & 4,12 \\
\hline $\mathbf{5 0 7}$ & 3,52 & $\mathbf{5 7}$ & 3,88 & $\mathbf{7 0 5}$ & 3,8 \\
\hline $\mathbf{1 1 2}$ & 3,44 & $\mathbf{2 1 1}$ & 3,84 & $\mathbf{1 2 1}$ & 3,88 \\
\hline
\end{tabular}

Sumber: Olahan Penulis

Pada indikator rasa, dari hasil uji hedonik rasa menurut 25 panelis agak terlatih menunjukkan pada pengulangan pertama sampel yang paling disukai, yaitu sampel dengan kode 507 (75\% tepung gaplek), pada pengulangan kedua sampel yang paling disukai, yaitu sampel dengan kode 057 (75\% tepung gaplek) dan pada pengulangan ketiga sampel yang paling disukai, yaitu sampel dengan kode 121 (100\% tepung gaplek). Secara keseluruhan pengulangan $(1,2,3)$ nilai rata-rata yang paling tinggi yaitu 3,92 (75\% tepung gaplek) pada sampel 057 di pengulangan kedua dan 121 di pengulangan ketiga.

Secara ringkas, hasil penelitian uji hedonik yang dilakukan penulis yaitu Uji Hedonik = Warna 50\% tepung gaplek - Aroma 50\% tepung gaplek - Tekstur 50\% tepung gaplek - Rasa $75 \%$ tepung gaplek \& 100\% tepung gaplek. Dalam uji pembedaan/ uji mutu hedonik terhadap subtitusi tepung gaplek dengan tepung terigu meliputi beberapa indikator yaitu warna, aroma, tekstur dan rasa. 
National Conference of Creative Industry: Sustainable Tourism Industry for Economic Development

Universitas Bunda Mulia, Jakarta, 5-6 September 2018 e-ISSN No: 2622-7436

Tabel 4. Uji Hedonik Rasa

\begin{tabular}{|c|c|c|c|c|c|}
\hline Sampel & Rata-rata & Sampel & Rata-rata & Sampel & Rata-rata \\
\hline \multicolumn{2}{|c|}{ Pengulangan 1 } & \multicolumn{2}{|c|}{ Pengulangan 2 } & \multicolumn{2}{c|}{ Pengulangan 3 } \\
\hline $\mathbf{1 5 2}$ & 3,04 & $\mathbf{2 1 5}$ & 3,44 & $\mathbf{5 1 2}$ & 3,24 \\
\hline $\mathbf{7 5}$ & 3,64 & $\mathbf{7 0 5}$ & 3,36 & $\mathbf{5 7 0}$ & 3,4 \\
\hline $\mathbf{5 0 7}$ & 3,72 & $\mathbf{5 7}$ & 3,92 & $\mathbf{7 0 5}$ & 3,56 \\
\hline $\mathbf{1 1 2}$ & 3,48 & $\mathbf{2 1 1}$ & 3,8 & $\mathbf{1 2 1}$ & 3,92 \\
\hline
\end{tabular}

Sumber: Olahan Penulis

Tabel 4. Uji Hedonik Warna

\begin{tabular}{|c|c|c|c|c|c|}
\hline Sampel & Rata-rata & Sampel & Rata-rata & Sampel & Rata-rata \\
\hline \multicolumn{2}{|c|}{ Pengulangan 1 } & \multicolumn{2}{|c|}{ Pengulangan 2 } & \multicolumn{2}{c|}{ Pengulangan 3 } \\
\hline $\mathbf{1 5 2}$ & 3,04 & $\mathbf{2 1 5}$ & 3,44 & $\mathbf{5 1 2}$ & 3,24 \\
\hline $\mathbf{7 5}$ & 3,64 & $\mathbf{7 0 5}$ & 3,36 & $\mathbf{5 7 0}$ & 3,4 \\
\hline $\mathbf{5 0 7}$ & 3,72 & $\mathbf{5 7}$ & 3,92 & $\mathbf{7 0 5}$ & 3,56 \\
\hline $\mathbf{1 1 2}$ & 3,48 & $\mathbf{2 1 1}$ & 3,8 & $\mathbf{1 2 1}$ & 3,92 \\
\hline
\end{tabular}

Sumber: Olahan Penulis

Pada Indikator warna dari hasil uji mutu hedonik warna menurut 25 panelis agak terlatih menunjukkan pada pengulangan pertama sampel yang paling disukai, yaitu sampel dengan kode 075 (50\% tepung gaplek), pada pengulangan kedua sampel yang paling disukai, yaitu sampel dengan kode 705 (75\% tepung gaplek) dan pada pengulangan ketiga sampel yang paling disukai, yaitu sampel dengan kode 570 (50\% tepung gaplek). Secara keseluruhan pengulangan $(1,2,3)$ nilai rata-rata yang paling tinggi yaitu 4,84 (50\% tepung gaplek) pada sampel 570 di pengulangan ketiga.

Tabel 4. Uji Hedonik Aroma

\begin{tabular}{|c|c|c|c|c|c|}
\hline Sampel & Rata-rata & Sampel & Rata-rata & Sampel & Rata-rata \\
\hline \multicolumn{2}{|c|}{ Pengulangan 1 } & \multicolumn{2}{|c|}{ Pengulangan 2 } & \multicolumn{2}{c|}{ Pengulangan 3 } \\
\hline $\mathbf{1 5 2}$ & 3,84 & $\mathbf{2 1 5}$ & 3,44 & $\mathbf{5 1 2}$ & 3,24 \\
\hline $\mathbf{7 5}$ & 4,12 & $\mathbf{7 0 5}$ & 4,2 & $\mathbf{5 7 0}$ & 4,4 \\
\hline $\mathbf{5 0 7}$ & 3,8 & $\mathbf{5 7}$ & 4,24 & $\mathbf{7 0 5}$ & 3,96 \\
\hline $\mathbf{1 1 2}$ & 3,12 & $\mathbf{2 1 1}$ & 3,56 & $\mathbf{1 2 1}$ & 3,24 \\
\hline
\end{tabular}

Sumber: Olahan Penulis

Pada Indikator aroma, dari hasil uji mutu hedonik aroma menurut 25 panelis agak terlatih menunjukkan pada pengulangan pertama sampel yang paling disukai, yaitu sampel dengan kode 075 (50\% tepung gaplek), pada pengulangan kedua sampel yang paling disukai, yaitu sampel dengan kode 075 (75\% tepung gaplek) dan pada pengulangan ketiga sampel yang paling disukai, yaitu sampel dengan kode 570 (50\% tepung gaplek). Secara keseluruhan pengulangan $(1,2,3)$ nilai rata-rata yang paling tinggi yaitu 4,4 (50\% tepung gaplek) pada sampel 570 di pengulangan ketiga. 
Pada Indikator tekstur, dari hasil uji mutu hedonik tekstur menurut 25 panelis agak terlatih menunjukkan pada pengulangan pertama sampel yang paling disukai, yaitu sampel dengan kode 075 (50\% tepung gaplek), pada pengulangan kedua sampel yang paling disukai, yaitu sampel dengan kode 057 (75\% tepung gaplek) dan pada pengulangan ketiga sampel yang paling disukai, yaitu sampel dengan kode 705 (75\% tepung gaplek). Secara keseluruhan pengulangan $(1,2,3)$ nilai rata-rata yang paling tinggi yaitu 4,12 (75\% tepung gaplek) pada sampel 057 di pengulangan kedua.

Pada Indikator rasa, dari hasil uji mutu hedonik rasa menurut 25 panelis agak terlatih menunjukkan pada pengulangan pertama sampel yang paling disukai, yaitu sampel dengan kode 112 (100\% tepung gaplek), pada pengulangan kedua sampel yang paling disukai, yaitu sampel dengan kode 057 (75\% tepung gaplek) dan 211 (100\% tepung gaplek), sedangkan pada pengulangan ketiga sampel yang paling disukai, yaitu sampel dengan kode 121 (100\% tepung gaplek). Secara keseluruhan pengulangan $(1,2,3)$ nilai rata-rata yang paling tinggi yaitu 3,84 (100\% tepung gaplek) pada sampel 112 di pengulangan pertama.

Tabel 4. Uji Hedonik Tekstur

\begin{tabular}{|c|c|c|c|c|c|}
\hline Sampel & Rata-rata & Sampel & Rata-rata & Sampel & Rata-rata \\
\hline \multicolumn{2}{|c|}{ Pengulangan 1 } & \multicolumn{2}{|c|}{ Pengulangan 2 } & \multicolumn{2}{c|}{ Pengulangan 3 } \\
\hline $\mathbf{1 5 2}$ & 3,84 & $\mathbf{2 1 5}$ & 3,72 & $\mathbf{5 1 2}$ & 3,76 \\
\hline $\mathbf{7 5}$ & 4 & $\mathbf{7 0 5}$ & 4 & $\mathbf{5 7 0}$ & 3,88 \\
\hline $\mathbf{5 0 7}$ & 3,72 & $\mathbf{5 7}$ & 4,12 & $\mathbf{7 0 5}$ & 4,08 \\
\hline $\mathbf{1 1 2}$ & 3,56 & $\mathbf{2 1 1}$ & 3,52 & $\mathbf{1 2 1}$ & 3,84 \\
\hline
\end{tabular}

Sumber: Olahan Penulis

Tabel 4. Uji Hedonik Rasa

\begin{tabular}{|c|c|c|c|c|c|}
\hline Sampel & Rata-rata & Sampel & Rata-rata & Sampel & Rata-rata \\
\hline \multicolumn{2}{|c|}{ Pengulangan 1} & \multicolumn{2}{|c|}{ Pengulangan 2} & \multicolumn{2}{|c|}{ Pengulangan 3} \\
\hline 152 & 2,72 & 215 & 3,32 & 512 & 3,16 \\
\hline 75 & 3,32 & 705 & 3,36 & 570 & 3,6 \\
\hline 507 & 3,56 & 57 & 3,8 & 705 & 3,72 \\
\hline 112 & 3,84 & 211 & 3,8 & 121 & 3,8 \\
\hline
\end{tabular}

Sumber: Olahan Penulis

Secara ringkas, hasil penelitian uji mutu hedonik yang dilakukan penulis, yaitu: Uji Mutu Hedonik = Warna 50\% tepung gaplek - Aroma 75\% tepung gaplek - Tekstur $75 \%$ tepung gaplek - Rasa $75 \%$ tepung gaplek \& $100 \%$ tepung gaplek.

\section{KESIMPULAN DAN IMPLIKASI}

Berdasarkan hasil penelitian, maka dapat disimpulkan bahwa pembuatan bolu kukus dapat disubtitusi sampai dengan 100\%. Mulai dari sampel 25\% tepung gaplek, $50 \%$ tepung gaplek, $75 \%$ tepung gaplek dan $100 \%$ tepung gaplek. Uji kesukaan 


\section{National Conference of Creative Industry: \\ Sustainable Tourism Industry for Economic Development}

Universitas Bunda Mulia, Jakarta, 5-6 September 2018

e-ISSN No: 2622-7436

(hedonik) dari segi warna yang paling disukai adalah sampel 705 subtitusi 50\% tepung gaplek pada pengulangan kedua, dari segi aroma yang paling disukai adalah sampel 570 subtitusi $50 \%$ tepung gaplek pada pengulangan ketiga, dari segi tekstur yang paling disukai adalah sampel 570 subtitusi 50\% tepung gaplek pada pengulangan ketiga, dari segi rasa yang paling disukai adalah sampel 057 subtitusi $75 \%$ tepung gaplek dan sampel 121 subtitusi 100\% tepung gaplek. Uji pembeda (mutu hedonik) dari segi warna yang paling disukaiadalah

sampel 570 subtitusi 50\% tepung gaplek pada pengulangan ketiga, dari segi aroma yang paling disukai adalah sampel 057 subtitusi $75 \%$ tepung gaplek pada pengulangan kedua, dari segi tekstur yang paling disukai adalah sampel 057 subtitusi $75 \%$ tepung gaplek pada pengulangan kedua dan dari segi rasa yang paling disukai adalah sampel 112 subtitusi $100 \%$ tepung gaplek pada pengulangan pertama.

\section{DAFTAR PUSTAKA}

Affandi, B., 2009. Pengaruh CO2 (Karbondioksida) Murni Terhadap Pertumbuhan Mikroorganisme Pada Produk Minuman Fanta Di PT. Coca- Cola Bottling Indonesia Unit Medan. FMIPA-USU, Medan.

Faridah, A. 2008. Patiseri Jilid 1 Untuk SMK. Jakarta: Direktorat Pembinaan Sekolah Menengah Kejuruan

Galih D M. 2014. Purwokerto (http://mc-tester.com/pembuatan-gaplek-dari-singkong/. (Diakses Juni 2015)

Harianja Vearanita. 2012. Bolu Chiffon Rainbow. http://veranitakwu2.blogspot.com/. (Diakses Maret2015)

Lies Suprapti. 2005. Tepung Tapioka Pembuatan dan Pemanfaatannya. Yogyakarta: Kanisius.

Lingga P. 1989. Bertanam Ubi-Ubian. Jakarta: PT Penebar Swadaya, Anggota IKAPI.

Nurosiyah Siti dan Winiati P. Rahayu. 2008. Evaluasi Sensori. Jakarta: Universitas Terbuka.

Purwono. 2009. Budidaya 8 Jenis Tanaman Unggul. Jakarta : Penebar Swadaya.

Rohimah Eneng. 2008. Garut. http://file.upi.edu/Direktori/FPTK/JUR._P END._KESEJAHTERAAN_KELUARG A/196005041986012-

ADE_JUWAEDAH/Bolu_kkus.pdf. (Diakses April 2015)

Siswono. 2005. Nutrisi Tidak Hanya Ada di Nasi. www.republika.co.id. (Diakses April 2015)

Sugiyono. 2012. Metode Penelitian Kuantitatif Kualitatif, R\&D. Bandung : Alfabeta.

Suhardjito, BA. 2006. Pastry Dalam Perhotelan. Yogyakarta: Andi.

Suliyanto. 2006. Metode Riset Bisnis.. Yogyakarta: Andi.

Winarno, F. G. 2008. Kimia Pangan dan Gizi. Jakarta: PT. Gramedia 